Editorial

\title{
Fault Diagnosis of Rotating Machine
}

\author{
Grzegorz Królczyk ${ }^{1}$, Zhixiong $\mathrm{Li}^{2, *}$ and Jose Alfonso Antonino Daviu ${ }^{3}$ \\ 1 Department of Manufacturing Engineering and Production Automation, Opole University of Technology, \\ 45-758 Opole, Poland; grzegorz.krolczyk@wp.pl \\ 2 School of Mechanical, Materials, Mechatronic and Biomedical Engineering, University of Wollongong, \\ Wollongong, NSW 2522, Australia \\ 3 School of Industrial Engineering, Universitat de València, 46010 València, Spain; joanda@die.upv.es \\ * Correspondence: zhixiong_li@uow.edu.au; Tel.: +61-0405-840-751
}

Received: 24 February 2020; Accepted: 25 February 2020; Published: 13 March 2020

check for updates

\section{Introduction}

Rotating machines have been used in a wide variety of industries, such as manufacturing tools [1-7], electric motors [8-17], wind turbines [18-21], aero-engines [22,23], mining machines [24-27], marine propulsions [28-31] and autonomous vehicles [32-36]. A tiny defect or a simple crack may result in severe damages to rotating machines [37]. As a result, it is crucial to monitor the health condition of rotating machines through active diagnostic and prognostic technologies [38]. In recent years, many detection techniques have been developed. These technologies include vibration analysis [18], oil analysis [30], thermography analysis [17], acoustic analysis [9], flux analysis [16], etc. This Special Issue invites original research papers that report on the state of the art and recent advancements in the fault diagnosis of rotating machines, so as to further promote practical applications of diagnostic and prognostic technologies.

\section{Content}

There are 18 papers selected for this Special Issue, representing the latest progress and advances in the diagnostics and prognostics of rotating machines. Regarding these 18 research papers, the following four research directions are specifically addressed:

Bearing elements fault detection: This Special Issue includes eight excellent examples of improving bearing fault detection. In the first paper, Duan et al. [39] improved the fault detection rate of a general rolling bearing by combining the local mean decomposition (LMD) and the ratio correction methods. Then, Cui et al. [40] discussed the diagnosis of multiple defects in a rolling bearing via vibration analysis; Shi et al. [41] reported a frequency matching linear transform technique for bearing fault detection under variable rotating speeds; moreover, Yin et al. [42] proposed a Huffman coding technique to identify bearing defect severity. By what follows, artificially intelligent techniques, including ensemble learning [43] and deep learning [44,45] were developed to detect bearing faults. In the last paper, the authors presented the application of acoustic emission analysis for bearing fault diagnosis [46].

Motor fault detection: Another four excellent papers have addressed motor fault detection. Goh and Kim [47] investigated the short circuit problem in an induction motor. Ishikawa and Igarashi [48] analyzed the demagnetization of a permanent magnet synchronous motor using finite element analysis. Glowacz [48] applied the acoustics analysis and Lee et al. [49] adopted the deep learning for motor failure detection.

Machine-level fault detection: This Special Issue includes five interesting papers for machine-level modelling and condition monitoring. Song et al. [50] diagnosed a superconducting rotating machine; Dineva et al. [51] applied fault pattern recognition for a rotating electrical Machine; 
Ding et al. [52] developed a vibration-based method to monitor a mining machine; Lv et al. [53] analyzed the multiple faults of the Apollo manned lunar landing system; and Xie et al. [54] modelled a marine platform based on temperature measurements.

Rotor fault detection: The last paper contained in this Special Issue presents a crack detection method for a rotor system [55].

\section{Summary}

Diagnostic and prognostic technologies for rotating machines are growing every month. The described work in this Special Issue has made a good contribution to the fault diagnosis of rotating machines. This collection of 18 papers is highly recommended and is believed to benefit readers in various aspects.

Author Contributions: All the authors contributed equally to the conception of the idea, implementing and analyzing the experimental results, and writing the manuscript. All authors have read and agreed to the published version of the manuscript.

Funding: This research was funded by Australia Research Council under grant number DE190100931.

Acknowledgments: The Guest Editors would like to thank all authors, reviewers and the editorial board of the MDPI Applied Science journal, and especially Xiaoyan Chen (Assistant Managing Editor) for their valuable contributions to this Special Issue.

Conflicts of Interest: The author declares no conflict of interest.

\section{References}

1. Mikolajczyk, T.; Paczkowski, T.; Pimenov, D.; Mia, M.; Patra, K.; Krolczyk, G.; Munish, K.; Zdrojewski, J. Analysis of the deviation in a low-cost system for stepless digital control of conventional lathe spindle speeds. Appl. Sci. 2019, 9, 12. [CrossRef]

2. Singh, S.; Prakash, C.; Antil, P.; Singh, R.; Królczyk, G.; Pruncu, C. Dimensionless analysis for investigating the quality characteristics of Aluminium matrix composites prepared through fused deposition modelling assisted investment casting. Materials 2019, 12, 1907. [CrossRef] [PubMed]

3. Jin, S.; Fan, D.; Malekian, R.; Duan, Z.; Li, Z. An image recognition method for gear fault diagnosis in the manufacturing line of short filament fibres. Insight 2018, 60, 270-275. [CrossRef]

4. Jin, S.; Lin, Q.; Yang, J.; Bie, Y.; Tian, M.; Li, Z. A novel information fusion method for vision perception and location of intelligent industrial robots. Elektron. Elektrotechnika 2019, 25, 4-10. [CrossRef]

5. Kumar, R.; Chattopadhyaya, S.; Hloch, S.; Krolczyk, G.; Legutko, S. Wear characteristics and defects analysis of friction stir welded joint of Aluminum alloy 6061-t6. Eksploat. I Niezawodn. Maint. Reliab. 2016, 18, 128-135. [CrossRef]

6. Jin, S.; Lin, Q.; Bie, Y.; Ma, Q.; Li, Z. A practical method for detecting fluff quality of fabric surface using optimal sensing. Elektron. Elektrotechnika 2020, 26, 20-24. [CrossRef]

7. Zhang, L.; Li, Z.; Królczyk, G.; Wu, D.; Tang, Q. Mathematical modeling and multi-attribute rule mining for energy efficient job-shop scheduling. J. Clean. Prod. 2019, 241, 118289. [CrossRef]

8. Glowacz, A. Recognition of acoustic signals of induction motor using FFT, SMOFS-10 and LSVM. Eksploat. I Niezawodn. Maint. Reliab. 2015, 17, 569-574. [CrossRef]

9. Glowacz, A. Recognition of acoustic signals of loaded synchronous motor using FFT, MSAF-5 and LSVM. Arch. Acoust. 2015, 40, 197-203. [CrossRef]

10. Glowacz, A.; Glowacz, Z. Recognition of rotor damages in a DC motor using acoustic signals. Bull. Pol. Acad. Sci. Technol. Sci. 2017, 65, 187-194. [CrossRef]

11. Glowacz, A.; Glowacz, W.; Kozik, J.; Piech, K.; Gutten, M.; Caesarendra, W.; Liu, H.; Brumercik, F.; Irfan, M.; Khan, Z.F. Detection of Deterioration of Three-phase Induction Motor using Vibration Signals. Meas. Sci. Rev. 2019, 19, 241-249. [CrossRef]

12. Glowacz, A. Acoustic fault analysis of three commutator motors. Mech. Syst. Signal Process. 2019, 133, 106226. [CrossRef] 
13. Iglesias-Martínez, M.; de Córdoba, P.; Antonino-Daviu, J.; Conejero, J. Detection of nonadjacent rotor faults in induction motors via spectral subtraction and autocorrelation of stray flux signals. IEEE T Ind. Appl. 2019, 55, 4585-4594. [CrossRef]

14. Yun, J.; Park, S.; Yang, C.; Lee, S.; Antonino-Daviu, J.; Sasic, M.; Stone, G. Airgap search coil-based detection of damper bar failures in salient pole synchronous motors. IEEE T Ind. Appl. 2019, 55, 3640-3648. [CrossRef]

15. Panagiotou, P.; Arvanitakis, I.; Lophitis, N.; Antonino-Daviu, J.; Gyftakis, K. A new approach for broken rotor bar detection in induction motors using frequency extraction in stray flux signals. IEEE T Ind. Appl. 2019, 55, 3501-3511. [CrossRef]

16. Garcia, M.; Panagiotou, P.; Antonino-Daviu, J.; Gyftakis, K. Efficiency assessment of induction motors operating under different faulty conditions. IEEE T Ind. Electron. 2018, 66, 8072-8081. [CrossRef]

17. Osornio-Rios, R.; Antonino-Daviu, J.; de Jesus Romero-Troncoso, R. Recent industrial applications of infrared thermography: A review. IEEE T Ind. Inform. 2018, 15, 615-625. [CrossRef]

18. He, C.; Li, H.; Li, Z.; Zhao, X. An improved bistable stochastic resonance and its application on weak fault characteristic identification of centrifugal compressor blades. J. Sound Vib. 2019, 442, 677-697. [CrossRef]

19. Li, Z.; Jiang, Y.; Guo, Q.; Hu, C.; Peng, Z. Multi-dimensional variational mode decomposition for bearing crack detection in wind turbines with large driving-speed variations. Renew. Energy 2018, 116, 55-73. [CrossRef]

20. Li, Z.; Yan, X.; Wang, X.; Peng, Z. Detection of gear cracks in a complex gearbox of wind turbines using supervised bounded component analysis of vibration signals collected from multi-channel sensors. J. Sound Vib. 2016, 371, 406-433. [CrossRef]

21. Bie, Y.; Guo, X.; Song, P.; Yang, J.; Li, Z. A novel design of flow structure model for online viscosity measurement. Insight 2019, 61, 9-14. [CrossRef]

22. Li, Z.; Goebel, K.; Wu, D. Degradation modeling and remaining useful life prediction of aircraft engines using ensemble learning. J. Eng. Gas Turb. Power 2019, 141, 041008. [CrossRef]

23. Li, Z.; Wu, D.; Hu, C.; Terpenny, J. An ensemble learning-based prognostic approach with degradation dependent weights for remaining useful life prediction. Reliab. Eng. Syst. Saf. 2019, 184, 110-122. [CrossRef]

24. Jiang, Y.; Li, Z.; Zhang, C.; Hu, C.; Peng, Z. On the bi-dimensional variational decomposition applied to nonstationary vibration signals for rolling bearing crack detection in coal cutters. Meas. Sci. Technol. 2016, 27, 065103. [CrossRef]

25. Li, Z.; Peng, Z. Nonlinear dynamic response of a multi-degree of freedom gear system dynamic model coupled with tooth surface characters: A case study on coal cutters. Nonlinear Dynam. 2016, 84, 271-286. [CrossRef]

26. Jiang, Y.; Zhu, H.; Li, Z.; Peng, Z. The nonlinear dynamics response of cracked gear system in a coal cutter taking environmental multi-frequency excitation forces into consideration. Nonlinear Dynam. 2016, 84, 203-222. [CrossRef]

27. Li, Z.; Jiang, Y.; Hu, C.; Peng, Z. Difference equation based empirical mode decomposition with application to separation enhancement of multi-fault vibration signals. J. Differ. Equ. Appl. 2017, 23, 457-467. [CrossRef]

28. Yang, K.; Hu, B.; Malekian, R.; Li, Z. An improved control-limit-based principal component analysis method for condition monitoring of marine turbine generators. J. Mar. Eng. Technol. 2020, 20, 1-8. [CrossRef]

29. Xi, W.; Li, Z.; Tian, Z.; Duan, Z. A feature extraction and visualization method for fault detection of marine diesel engines. Measurement 2018, 116, 429-437. [CrossRef]

30. Yan, X.; Xu, X.; Sheng, C.; Yuan, C.; Li, Z. Intelligent wear mode identification system for marine diesel engines based on multi-level belief rule base methodology. Meas. Sci. Technol. 2017, 29, 015110. [CrossRef]

31. Li, Z.; Peng, Z. A new nonlinear blind source separation method with chaos indicators for decoupling diagnosis of hybrid failures: A marine propulsion gearbox case with a large speed variation. Chaos Soliton. Fract. 2016, 89, 27-39. [CrossRef]

32. Zhang, C.; Peng, Z.; Chen, S.; Li, Z.; Wang, J. A gearbox fault diagnosis method based on frequency-modulated empirical mode decomposition and support vector machine. P. I Mech. Eng. C-J. Mec. 2018, 232, 369-380. [CrossRef]

33. Li, Z.; Guo, Z.; Hu, C.; Li, A. On-line indicated torque estimation for internal combustion engines using discrete observer. Comput. Electr. Eng. 2017, 60, 100-115.

34. Zhang, X.; Li, Z.; Wang, J. Friction prediction of rolling-sliding contact in mixed EHL. Measurement 2017, 100, 262-269. [CrossRef] 
35. Zhang, C.; Li, Z.; Hu, C.; Chen, S.; Wang, J.; Zhang, X. An optimized ensemble local mean decomposition method for fault detection of mechanical components. Meas. Sci. Technol. 2017, 28, 035102. [CrossRef]

36. Krolczyk, J.; Krolczyk, G.; Legutko, S.; Napiorkowski, J.; Hloch, S.; Foltys, J.; Tama, E. Material flow optimization-A case study in automotive industry. Teh. Vjesn. Technol. Gaz. 2015, 22, 1447-1456.

37. Li, Z.; Jiang, Y.; Hu, C.; Peng, Z. Recent progress on decoupling diagnosis of hybrid failures in gear transmission systems using vibration sensor signal: A review. Measurement 2016, 90, 4-19. [CrossRef]

38. Li, Z.; Liu, F.; Sun, S.; Sarkodie-Gyan, T.; Li, W. Decoupling of multiple concurrent faults for diagnosing coal cutter gearboxes: An extensive experimental investigation with multichannel sensor measurements. $J$. Nondestruc. Eval. Diagn. Progn. Eng. Syst. 2019, 2, 041001. [CrossRef]

39. Duan, Y.; Wang, C.; Chen, Y.; Liu, P. Improving the accuracy of fault frequency by means of local mean decomposition and ratio correction method for rolling bearing failure. Appl. Sci. 2019, 9, 1888. [CrossRef]

40. Cui, L.; Du, J.; Yang, N.; Xu, Y.; Song, L. Compound faults feature extraction for rolling bearings based on parallel dual-Q-factors and the improved maximum correlated kurtosis deconvolution. Appl. Sci. 2019, 9, 1681. [CrossRef]

41. Shi, J.; Du, G.; Ding, R.; Zhu, Z. Time frequency representation enhancement via frequency matching linear transform for bearing condition monitoring under variable speeds. Appl. Sci. 2019, 9, 3828. [CrossRef]

42. Yin, J.; Lei, M.; Zheng, H.; Yang, Y.; Li, Y.; Xu, M. The Average coding length of Huffman coding based signal processing and its application in fault severity recognition. Appl. Sci. 2019, 9, 5051. [CrossRef]

43. Han, L.; Yu, C.; Liu, C.; Qin, Y.; Cui, S. Fault diagnosis of rolling bearings in rail train based on exponential smoothing predictive segmentation and improved ensemble learning algorithm. Appl. Sci. 2019, 9, 3143. [CrossRef]

44. Dai, J.; Tang, J.; Shao, F.; Huang, S.; Wang, Y. Fault diagnosis of rolling bearing based on multiscale intrinsic mode function permutation entropy and a stacked sparse denoising autoencoder. Appl. Sci. 2019, 9, 2743. [CrossRef]

45. Zan, T.; Wang, H.; Wang, M.; Liu, Z.; Gao, X. Application of multi-dimension input convolutional neural network in fault diagnosis of rolling bearings. Appl. Sci. 2019, 9, 2690. [CrossRef]

46. Goh, Y.-J.; Kim, O. Linear method for diagnosis of inter-turn short circuits in 3-phase induction motors. Appl. Sci. 2019, 9, 4822. [CrossRef]

47. Ishikawa, T.; Igarashi, N. Failure Diagnosis of demagnetization in interior permanent magnet synchronous motors using vibration characteristics. Appl. Sci. 2019, 9, 3111. [CrossRef]

48. Glowacz, A. Recognition of acoustic signals of commutator motors. Appl. Sci. 2018, 8, 2630. [CrossRef]

49. Lee, J.-H.; Pack, J.-H.; Lee, I.-S. Fault diagnosis of induction motor using convolutional neural network. Appl. Sci. 2019, 9, 2950. [CrossRef]

50. Song, S.; Ko, T.K.; Choi, Y.; Lee, S. A novel fault diagnosis method for high-temperature superconducting field coil of superconducting rotating machine. Appl. Sci. 2020, 10, 223. [CrossRef]

51. Dineva, A.; Mosavi, A.; Gyimesi, M.; Vajda, I.; Nabipour, N.; Rabczuk, T. Fault diagnosis of rotating electrical machines using multi-label classification. Appl. Sci. 2019, 9, 5086. [CrossRef]

52. Ding, H.; Wang, Y.; Yang, Z.; Pfeiffer, O. Nonlinear blind source separation and fault feature extraction method for mining machine diagnosis. Appl. Sci. 2019, 9, 1852. [CrossRef]

53. Lv, X.; Zhou, D.; Ma, L.; Tang, Y. Dependency model-based multiple fault diagnosis using knowledge of test result and fault prior probability. Appl. Sci. 2019, 9, 311. [CrossRef]

54. Xie, Y.; Zheng, Z.; Wang, H.; Xu, Z.; Liu, G.; Malekian, R.; Li, Z. Analysis of a main cabin ventilation system in a jack-up offshore platform part I: Numerical modelling. Appl. Sci. 2019, 9, 3185. [CrossRef]

55. Xie, J.; Chen, J.; Peng, Y.; Zi, Y. A new concept of instantaneous whirling speed for cracked rotor's axis orbit. Appl. Sci. 2019, 9, 4120. [CrossRef]

(C) 2020 by the authors. Licensee MDPI, Basel, Switzerland. This article is an open access article distributed under the terms and conditions of the Creative Commons Attribution (CC BY) license (http://creativecommons.org/licenses/by/4.0/). 